\title{
Effect of Post Harvest Chemical Treatment on the Post Harvest Life of Jasmine (Jasminum sambac L. Aiton) Flowers
}

\author{
K. G. Varpe*, G.D. Shirke and K.H. Pujari
}

Department of Post Harvest Management of fruit, Vegetable and Flower crops, Faculty of Agriculture, Post Graduate Institute of Post Harvest management of Dr.Balasaheb Sawant Konkan Krishi Vidypeeth, Dapoli, India

*Corresponding author

\begin{tabular}{|l|}
\hline \multicolumn{1}{|l}{} \\
\hline Key w o r d s \\
Jasmine, Post \\
harvest, Chemical, \\
Boric acid, \\
Freshness, \\
Fragrance \\
\hline Article Info \\
\hline $\begin{array}{l}\text { Accepted: } \\
10 \text { July } 2020 \\
\text { Available Online: } \\
10 \text { August } 2020\end{array}$ \\
\hline \hline
\end{tabular}

\section{A B S T R A C T}

Investigation was carried out in the Department of Post harvest Management of fruit, Vegetable and Flower crops, Faculty of Agriculture, Post Graduate Institute of Post Harvest management of Dr.Balasaheb Sawant Konkan Krishi Vidypeeth, Dapoli during 2018-2019 to find out the effect of post harvest chemical treatment on post harvest life of Jasmine (Jasminum sambac L. Aiton) in Factorial Completely randomized Design (FCRD) with Ten treatment and three replications. Packaging material of polyethylene (PE) bags 200 gauge without ventilation is used. The periodical observations recorded every $24 \mathrm{hrs}$ from $0 \mathrm{hrs}$ to $72 \mathrm{hrs}$. were physiological loss of weight, freshness index, flower opening index, colour retention score, fragrance index and shelflife. Results of this experiment envisaged that flowers treated with $4 \%$ boric acid proved effective in extending shelf life of Jasmine flower buds up to 81 hours with less physiological loss of weight, flower opening index, colour retention score and fragrance index and high freshness index and shelflife.

\section{Introduction}

Mogra (Jasmine) is one of the most important commercial flower crop widely cultivated in India and esteemed for its attractive fragrant flowers. The genus Jasminum have more than 200 species, among them 04 are cultivated commercially in India. Among the important species of jasmine, Jasminum sambac is the most common, is also known as Arabian Jasmine. The term jasmine is derived from an Arabic word "Jessamine" and in Persian language it is called as "Yasmin" or "Yasmyn" which means fragrance (Bailey, 1947). Jasmine oils are used for manufacture of cosmetics, soaps, confectionary perfumes, perfumed tobacco, syrups, aerated water, ointments, disinfectants and detergents. 
Flowers are used for making garland, hair adornments of woman and for medicinal purpose. The fragrance of jasmine flower cannot be imitated by any one of the known synthetic aromatic chemicals (Bhattacharjee, 1980). The annual production of flowers in India is more than 199.26 MT and in Maharashtra, it is 2.46 MT (Anon., 2018). In India, if we avoid wastage of horticultural produce up to $2 \%$ from field to market, there will be saving of 100 to 200 crores per year (Ramana et al., 1988). Keeping this in mind, A study was undertaken to increase shelflife of jamine flower with giving different pre chemical treatment.

\section{Materials and Methods}

The present research was carried out in the department of Post Harvest Management of Fruit, Vegetable and Flower crops, college Post Graduate Institute of Post Harvest Management. Killa-Roha, Raigad, Maharshtra during 2018-19. This experiment was laid out in Factorial Completely Randomized Design with 10 treatments and 3 replication. The treatments are: T1 - 1\% Sucrose solution T2$2 \%$ Sucrose Solution, T3- 3\% Sucrose solution, T4- 2\% Boric acid, T5- 4\% Boric acid, T6-6\% Boric acid, T7- 100 ppm Sodium benzoate solution, T8- 150 ppm Sodium benzoate solution, T9- 200 ppm Sodium benzoate solution and T10- Control (Distilled water treatment). Flowers are kept in 200 gauge polythene bag and stored at $12 \pm 1{ }^{\circ} \mathrm{C}$. $50 \mathrm{~g}$ of uniform size, freshly harvested flowers are used for each treatments and observation like physiological loses of weight (PLW), freshness score, fragrance score, colour retention score, flower opening index and shelf life were recorded during storage of flowers at 24 hours of intervals.

Physiological loses of weight was calculated by subtracting fresh weight of flowers at the time of packing and at $12^{\text {th }}, 24^{\text {th }}$, and $36^{\text {th }}$ hr. after harvesting of flowers and expressed as percentage. Visual parameters like freshness and fragrance score which is used by Madaiah, (1991) and colour retention score were recorded based on scale, the score was expressed on 0 to 4 and average was calculated. Shelf life of the flower was measured as time taken to wilt $50 \%$ of flowers. The resulted data were statistically analyzed using the method of Panase and Sukhatme (1967) and Amdekar (2014).

\section{Result and Discussion}

The result obtained in respect of post harvest pre chemical treatment effect and shefllife of Jasmine flower viz., freshness index, fragrance score, flower opening index, colour retention score, physiological loss in weight and shelflife flowers revealed that there were significant effect of post harvest chemical treatment.

\section{Effect on physiological loss in weight of jasmine flower during storage period}

The data in respect to the effect on physiological loss in weight of jasmine flower during storage period are presented in Table 1. There were significant effects of various post harvest treatment on physiological loss weight of jasmine flowers. The treatment $T_{5}$ (1.15) have less PLW, were significantly superior to all other treatment. The treatment T10 were recorded higher PLW i.e., (4.01).Similar result was observed by Jawaharlal et al., (2012) in jasmine flowers.

\section{Effect on Freshness index of jasmine flower during storage period}

The data respect to freshness index is presented in Table 2. The treatment T10 (83.62) were recorded less freshness index and the treatment T5 (97.13) were recorded higher freshness index which was 
significantly different with the all other treatment. The treatment T5 was at par with treatment $\mathrm{T} 6$. The treatment $\mathrm{T} 5$ were recorded higher freshness index (90.90) at 72 hours of storage period. Similar result was observed by Manimaran et al., (2108) and Patel et al., (2017) during storage study on jasmine flowers.

\section{Effect on flower opening index of jasmine flower during storage period}

The data pertaining to the flower opening index during storage period are shown in the Table no. 3. The treatment T5 $(6.38 \%)$ were recorded lowest mean flower opening index and which was significantly different with all other treatment. The lowest flower index (0.24) was recorded at 24 hours of storage period and highest flower opening index (34.80) was recorded at 72 hours of storage period. Similar result was observed by Karuppaiah et al., (2006) and Patel et al., (2017) during storage study on jasmine flowers.

\section{Effect on colour retention score of jasmine flower during storage period}

The data related to colour retention score of jasmine flower during storage period are shown in Table 4. The treatment T10 recorded lower colour retention score i.e. (2.88). The treatment T3 was recorded higher colour retention score which was found significantly superior over all other treatments. However the treatment T2 (3.29), T5 (3.25) and T6 (3.25) were found at par with the treatment T3. Similar result was also recorded Yathindra et al., (2018) in jasmine flower.

Table.1 Effect on physiological loss in weight of jasmine flower during storage period

\begin{tabular}{|c|c|c|c|c|c|}
\hline \multirow[t]{3}{*}{ Treatment } & \multicolumn{4}{|c|}{ Physiological loss in weight (\%) } & \multirow[t]{3}{*}{ Mean } \\
\hline & \multicolumn{4}{|c|}{ Storage period (hours) } & \\
\hline & $\mathbf{0}$ & 24 & 48 & 72 & \\
\hline T1 & 0 & 1.95 & 5.33 & 7.99 & 3.82 \\
\hline $\mathbf{T 2}$ & 0 & 0.65 & 2.73 & 6.11 & 2.37 \\
\hline T3 & 0 & 1.65 & 4.33 & 7.37 & 3.34 \\
\hline T4 & 0 & 1.74 & 3.29 & 5.22 & 2.56 \\
\hline T5 & 0 & 0.50 & 1.55 & 2.54 & 1.15 \\
\hline T6 & 0 & 0.89 & 2.86 & 4.68 & 2.11 \\
\hline T7 & 0 & 1.64 & 4.57 & 8.16 & 3.59 \\
\hline T8 & 0 & 1.35 & 3.64 & 7.22 & 3.05 \\
\hline T9 & 0 & 1.15 & 4.58 & 7.72 & 3.36 \\
\hline T10 & 0 & 1.45 & 4.30 & 10.29 & 4.01 \\
\hline \multirow[t]{2}{*}{ Mean } & 0 & 1.30 & 3.72 & 6.73 & \\
\hline & \multicolumn{2}{|c|}{ S.Em \pm} & \multicolumn{3}{|c|}{ CD at $5 \%$} \\
\hline Treatments (T) & \multicolumn{2}{|c|}{0.13} & & 0.37 & \\
\hline Storage (S) & \multicolumn{2}{|c|}{0.08} & & \multirow{2}{*}{$\begin{array}{c}0.24 \\
\text { NS }\end{array}$} & \\
\hline Interaction $(\mathbf{T} \times S)$ & \multicolumn{2}{|c|}{0.26} & & & \\
\hline
\end{tabular}


Table.2 Effect on Freshness index of jasmine flower during storage period

\begin{tabular}{|c|c|c|c|c|c|}
\hline \multirow[t]{3}{*}{ Treatment } & \multicolumn{4}{|c|}{ Freshness index } & \multirow[t]{3}{*}{ Mean } \\
\hline & \multicolumn{4}{|c|}{ Storage period (hours) } & \\
\hline & $\mathbf{0}$ & 24 & 48 & 72 & \\
\hline T1 & 100.00 & 95.47 & 92.71 & 78.49 & 91.67 \\
\hline $\mathbf{T} 2$ & 100.00 & 96.27 & 92.91 & 80.77 & 92.49 \\
\hline T3 & 100.00 & 96.64 & 93.22 & 81.76 & 92.91 \\
\hline T4 & 100.00 & 97.95 & 96.54 & 90.39 & 96.22 \\
\hline T5 & 100.00 & 98.79 & 98.81 & 90.90 & 97.13 \\
\hline T6 & 100.00 & 97.72 & 97.18 & 90.43 & 96.33 \\
\hline T7 & 100.00 & 95.20 & 88.69 & 75.33 & 89.80 \\
\hline T8 & 100.00 & 95.22 & 89.78 & 76.59 & 90.40 \\
\hline T9 & 100.00 & 95.72 & 90.31 & 77.82 & 90.96 \\
\hline T10 & 100.00 & 88.80 & 77.46 & 68.24 & 83.62 \\
\hline \multirow[t]{2}{*}{ Mean } & 100.00 & 95.78 & 91.89 & 80.44 & \\
\hline & \multicolumn{2}{|c|}{ S.Em \pm} & \multicolumn{3}{|c|}{ CD at $5 \%$} \\
\hline Treatments $(\mathbf{T})$ & \multicolumn{2}{|c|}{0.20} & & 0.55 & \\
\hline Storage (S) & \multicolumn{2}{|c|}{0.12} & & \multirow{2}{*}{$\begin{array}{l}0.35 \\
\text { NS }\end{array}$} & \\
\hline Interaction $(\mathbf{T} \times \mathbf{S})$ & \multicolumn{2}{|c|}{0.39} & & & \\
\hline
\end{tabular}

Table.3 Effect on flower opening index of jasmine flower during storage period

\begin{tabular}{|c|c|c|c|c|c|}
\hline \multirow[t]{3}{*}{ Treatment } & \multicolumn{4}{|c|}{ Flower opening index } & \multirow[t]{3}{*}{ Mean } \\
\hline & \multicolumn{4}{|c|}{ Storage period (hours) } & \\
\hline & $\mathbf{0}$ & 24 & 48 & 72 & \\
\hline T1 & 0 & 5.55 & 13.25 & 33.54 & 13.84 \\
\hline $\mathbf{T 2}$ & 0 & 6.75 & 14.73 & 37.13 & 14.65 \\
\hline T3 & 0 & 7.70 & 16.37 & 40.66 & 16.18 \\
\hline T4 & 0 & 1.47 & 3.92 & 28.57 & 8.49 \\
\hline T5 & 0 & 0.24 & 4.44 & 20.83 & 6.38 \\
\hline T6 & 0 & 0.71 & 4.97 & 26.99 & 8.17 \\
\hline $\mathbf{T 7}$ & 0 & 8.90 & 17.88 & 42.04 & 17.21 \\
\hline T8 & 0 & 9.87 & 21.35 & 42.80 & 18.50 \\
\hline T9 & 0 & 11.28 & 23.46 & 43.09 & 19.46 \\
\hline T10 & 0 & 17.82 & 57.49 & 63.90 & 34.80 \\
\hline \multirow[t]{2}{*}{ Mean } & 0 & 6.96 & 17.85 & 38.26 & \\
\hline & \multicolumn{2}{|c|}{ S.Em \pm} & \multicolumn{3}{|c|}{ CD at $5 \%$} \\
\hline Treatments (T) & \multicolumn{2}{|c|}{0.38} & \multicolumn{3}{|c|}{1.07} \\
\hline Storage (S) & \multicolumn{2}{|c|}{0.24} & \multicolumn{3}{|c|}{0.68} \\
\hline Interaction $(\mathbf{T} \times \mathbf{S})$ & \multicolumn{2}{|c|}{0.76} & \multicolumn{3}{|c|}{ NS } \\
\hline
\end{tabular}


Table.4 Effect on colour retention score of jasmine flower during storage period

\begin{tabular}{|c|c|c|c|c|c|}
\hline \multirow[t]{3}{*}{ Treatment } & \multirow{2}{*}{\multicolumn{4}{|c|}{$\begin{array}{l}\text { Colour retention score } \\
\text { Storage period (hours) }\end{array}$}} & \multirow[t]{3}{*}{ Mean } \\
\hline & & & & & \\
\hline & 0 & 24 & 48 & 72 & \\
\hline T1 & 4.00 & 3.67 & 2.67 & 2.33 & 3.17 \\
\hline T2 & 4.00 & 3.50 & 3.00 & 2.67 & 3.29 \\
\hline T3 & 4.00 & 3.33 & 3.00 & 3.00 & 3.33 \\
\hline T4 & 4.00 & 3.33 & 3.00 & 2.50 & 3.21 \\
\hline T5 & 4.00 & 3.00 & 3.00 & 3.00 & 3.25 \\
\hline T6 & 4.00 & 3.17 & 3.00 & 2.83 & 3.25 \\
\hline $\mathbf{T 7}$ & 4.00 & 3.33 & 2.67 & 2.33 & 3.08 \\
\hline T8 & 4.00 & 3.33 & 2.67 & 2.17 & 3.04 \\
\hline T9 & 4.00 & 3.33 & 3.00 & 2.17 & 3.13 \\
\hline T10 & 4.00 & 3.33 & 2.17 & 2.00 & 2.88 \\
\hline \multirow[t]{2}{*}{ Mean } & 4.00 & 3.33 & 2.82 & 2.50 & \\
\hline & \multicolumn{2}{|c|}{ S.Em \pm} & \multicolumn{3}{|c|}{ CD at $5 \%$} \\
\hline Treatments (T) & \multicolumn{2}{|c|}{0.10} & \multicolumn{3}{|c|}{0.29} \\
\hline Storage (S) & \multicolumn{2}{|c|}{0.07} & \multicolumn{3}{|c|}{0.19} \\
\hline Interaction $(\mathbf{T} \times \mathbf{S})$ & \multicolumn{2}{|c|}{0.21} & \multicolumn{3}{|c|}{ NS } \\
\hline
\end{tabular}

Table.5 Effect on fragrance index and shelflife of jasmine flower during storage period

\begin{tabular}{|c|c|c|c|c|c|c|}
\hline \multirow[t]{3}{*}{ Treatment } & \multicolumn{4}{|c|}{ Fragrance index } & \multirow[t]{3}{*}{ Mean } & \multirow{3}{*}{$\begin{array}{c}\text { Shellife } \\
\text { (Hrs.) }\end{array}$} \\
\hline & \multicolumn{4}{|c|}{ Storage period (hours) } & & \\
\hline & $\mathbf{0}$ & 24 & 48 & 72 & & \\
\hline T1 & 2.00 & 2.67 & 3.00 & 3.33 & 2.75 & 68.12 \\
\hline T2 & 2.33 & 2.67 & 3.00 & 3.33 & 2.83 & 69.94 \\
\hline T3 & 2.00 & 2.33 & 3.00 & 3.33 & 2.67 & 70.74 \\
\hline T4 & 2.00 & 2.33 & 3.00 & 3.17 & 2.63 & 82.58 \\
\hline T5 & 2.00 & 2.17 & 2.33 & 3.00 & 2.38 & 84.00 \\
\hline T6 & 2.00 & 2.00 & 3.00 & 3.17 & 2.54 & 77.67 \\
\hline $\mathbf{T} 7$ & 2.00 & 3.00 & 3.33 & 3.83 & 3.04 & 61.59 \\
\hline T8 & 2.00 & 2.67 & 3.33 & 3.83 & 2.96 & 62.61 \\
\hline T9 & 2.00 & 2.39 & 2.89 & 3.33 & 2.65 & 64.91 \\
\hline T10 & 2.00 & 2.33 & 3.00 & 3.67 & 2.75 & 51.12 \\
\hline \multirow[t]{2}{*}{ Mean } & 2.03 & 2.46 & 2.99 & 3.40 & & \\
\hline & \multicolumn{3}{|c|}{ S.Em \pm} & \multicolumn{3}{|c|}{ CD at $5 \%$} \\
\hline Treatments (T) & \multicolumn{3}{|c|}{0.10} & \multicolumn{3}{|c|}{0.27} \\
\hline Storage (S) & \multicolumn{3}{|c|}{0.06} & \multicolumn{3}{|c|}{0.17} \\
\hline Interaction $(\mathbf{T} \times S)$ & \multicolumn{3}{|c|}{0.19} & \multicolumn{3}{|c|}{ NS } \\
\hline
\end{tabular}




\section{Photograph-1}
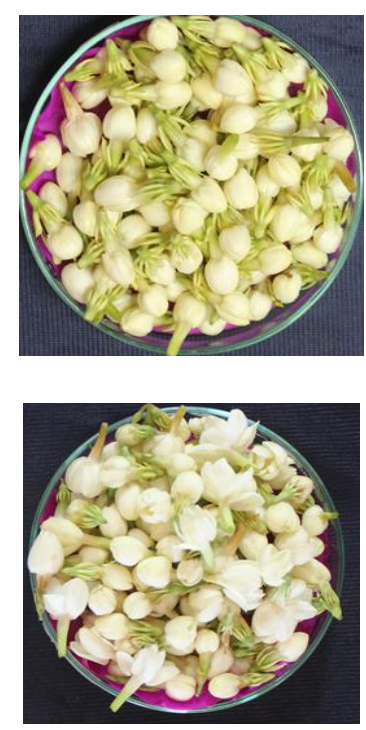

Effect on fragrance index and shelflife of jasmine flower during storage period

The data pertaining to the fragrance index an shelflife of jasmine flower during storage period are shown in Table 5. A significant difference was found in the fragrance index of jasmine buds in all the treatments. The treatment $\mathrm{T} 5$ recorded the lowest (2.38) mean value for fragrance index and it was at par with the treatments $\mathrm{T} 6$ [6\% boric acid] and the treatment T4. The highest (3.04) mean value for fragrance index was observed in the treatment $\mathrm{T} 7$ were was at par the treatments $\mathrm{T} 8$ and T2. The similar result recorded by Yathindra et al., (2018).

The highest shelflife (84.00 hours) of jasmine flower was recorded in treatment $\mathrm{T} 5$ and this treatment was superior to all other treatments followed the treatment T4, T6 and treatment T3.Similar observation was made by Thamaraiselvi et al., (2010) in Jasminum sambac and Nirmala and Reddy (1993) was also observed significant increase in shelf life due to packaging and storage conditions in jasmine.
$4 \%$ treated flowers after 72 hours

Untreated flowers after 72 hours

\section{Acknowledgement}

The authors wish to thanks Research guide, Associate Dean, Post graduate Institute of Post Harvest Management, Killa-Roha, Raigad, Maharashtra and Head, Department of Post Harvest Management of Fruit, Vegetable and Flower crops, PGIPHM, KillaRohaRaigad, Maharashtra for providing necessary facility in conducting the experiment.

\section{References}

Amdekar, S. J. (2014). Statistical Method for Agricultural and Biological Sciences. Narosa Publishing House Private Limited. New Delhi.

Anonymous, (2018). https://www.indiaagristat.com/table/Agr iculture -data/2/horticulture/118/ 1157858/ data.aspx.

Bailey, L.H. (1951). Manual of cultivated plants. The McMillan Co., New York. (Pp.7-9).

Bhattacharjee, S.K., (1980). Native Jasmine of India. Indian perfumer, 24 (3): 126- 
133.

Jawaharlal, M., Thamaraiselvi, S. P., and Ganga, M. (2012). Packaging technology for export of jasmine (Jasminum sambac Ait.) flowers. Journal of Horticultural Science, 7(2): 180-189.

Madaiah, D. (1991). Postharvest response of Jasminum multiflorum and Polianthes tuberosa flowers to packaging and cool chamber storage (Doctoral dissertation, University of Agricultural Sciences; Bangalore).

Manimaran, P., Ganga, M., Kannan, M. and Arulmozhiselvan, K. (2018). Standardization of post harvest management techniques for Jasminum nitidum flowers. ChemSci Rev Lett. 7(26), 652-658.

Nirmala, S. and Reddy, T. V. (1993). Extension of shelf life of Jasminum multiflorum through packaging. Journal of Maharashtra Agricultural University, 27: 272-276.

Panse, V. G. and Sukhatme, P. V. (1967). Statistical methods for agricultural workers. Indian Council for
Agricultural Research. New Delhi.

Patel, M., Ganga, M., Jawaharlal, M. and Jeyakumar, P. (2017). Assessment of qualitative, quantitative and visual flower quality parameters of certain commercial jasmine varieties during peak flowering season. Int. J. Curr. Microbiol. App. Sci, 6(11): 3246-3251.

Ramana KV, Rodoviguez R, Rao V. Packaging of fresh fruits and vegetables. Ibid, 1988, 31-38.

Thamaraiselvi, S. P., Jawaharlal, M., Ganga, M., and Varadharaju, N. (2010). Packaging technology for long term storage of jasmine (Jasminum sambacAit.) flowers. Journal of Ornamental Horticulture, 13(3): 171181.

Yathindra, H. A., Keerthishankar, K., Rajesh, A. M., Harshavardhan, M., Mutthuraju, G. P., and Mangala, K. P. (2018). Packaging technology for extending shelf life of jasmine (Jasminum sambac CV. MysuruMallige) flowers. Journal of Pharmacognosy and Phytochemistry., (SP3): 257-259.

\section{How to cite this article:}

Varpe, K.G., G.D. Shirke and Pujari, K.H. 2020. Effect of Post Harvest Chemical Treatment on the Post Harvest Life of Jasmine (Jasminum sambac L. Aiton) Flowers. Int.J.Curr.Microbiol.App.Sci. 9(08): 502-508. doi: https://doi.org/10.20546/ijcmas.2020.908.057 